УДК 338.4

JEL: O33:38

DOI: http://doi.org/10.32750/2019-0104

\author{
Дульська Ірина Василівна \\ к.e.H., C.H.C. \\ Державна установа «Інститут економіки та прогнозування» НАН України, \\ Київ, Україна \\ ORCID 0000-0002-2657-8375 \\ e-mail:i_dulska@i.ua
}

\title{
ПРОБЛЕМИ АДАПТАЦІЇ СТАТИСТИКИ ШИРОКОСМУГОВОГО ДОСТУПУ ДО МЕРЕЖІ ІНТЕРНЕТ В УКРАЇНІ ДО МІЖНАРОДНИХ ІНДИКАТОРІВ
}

\begin{abstract}
Анотація. В статті досліджуються методологічні проблеми адаптації статистики широкосмугового доступу до мережі Інтернет (ШСД) в Україні до міжнародних індикаторів срери європейського чифрового табло та індексу DESI в частині ШСД, індикаторів інших міжнародних організачій в чій сфері. Встановлено, що через невиконання урядових рішень щодо визначення індексів, індикаторів та методик оцінювання цифрового розвитку України відповідно до міжнародних практик, офіційна статистика продовжує використовувати показники, що не дозволяють в повній мірі здійснювати міжнародні порівняння, розробляти стратегічні документи щодо перспектив розвитку ШСД в країні. Не гармонізовано з європейськими підходами аналіз діапазонів швидкостей ШСД. Це не дозволяє оцінювати ступінь проникнення передових технологій (звичайний, швидкий, надшвидкий ШСД). Дані щодо покриття 3-4G технологіями зв'язку фрагментарні. Відрізняються термінологічні підходи до визначення технологій підключення і передачі даних, об'єкту надання послуг (в ЄС ним $\epsilon$ домогосподарство, в Україні - абонент), способу встановлення договірних відносин щодо надання послуг ШСД (контракт з ідентифікацією підписчика чи анонімна передплата). В Україні значною мірою офічійно не публікується статистика, яка вимагається від суб'єктів господарювання згідно форм державних статистичних спостережень. В той же час Міжнародний Союз Електрозв'язку публікує значний діапазон статистичних даних, які не оприлюднює офічійна статистика в Україні, - фінансові показники, обсяг інвестичій, цін (не співпадають з європейськими підходами до формування послуг кошику ШСД),

податкового навантаження на споживачів послуг ШСД.

Запропоновано структуруфоормування в України аналога показника DESI 1 b3 Spectrum, який в $\in C$ не розраховується з 2018 р., оскільки його чілі досягнуті. Для країни з перехідною економікою, де лише формуються інституційні засади ринкової економіки, суспільства та єзначне технологічне відставання, він є доцільним. До статистичної бази слід своєчасно вносити показники, які відображають нові явища в срері, наприклад, ступінь розвитку 5 G.
\end{abstract}

Ключові слова: широкосмуговий доступ до Інтернет (ШСД); фіксований і мобільний ШСД; європейське чифрове табло DESI з ШСД; статистика ШСД в Україні; сумісність показників; швидкість ШСД; абонент ШСД; ціни кошика послуг ШСД.

(ㄱ. В. Дульська, 2019

\footnotetext{
${ }^{1}$ Стаття виконана в рамках науково-дослідної роботи «Цифрові технології в інноваційній трансформації економіки України», державний реєстраційний номер $0118 \mathrm{U} 007629$
} 


\section{ВСТУП}

Однією з необхідних передумов розвитку цифрового суспільства та економіки в Україні $\epsilon$ розгортання стаціонарних (оптичних, дротових, фіксованих (fixed (f-)) і мобільних (безпроводових (mobile (m-)) мереж високошвидкісного широкосмугового доступу до Інтернет (ШСД). Крім високої швидкості, ШСД забезпечує безперервне підключення до Інтернету через двосторонній (дуплексний) зв'язок - можливість одночасно приймати і передавати інформацію на високих швидкостях в обидві сторони. Через збільшення значущості ШСД у 2011 р. ООН визнала право на ШСД одним з базових прав людини. Тому держава має сприяти моніторингу розвитку ШСД, зокрема за рахунок відповідної політики державних статистичних спостережень.

Постановка проблеми. На жаль, досі не виконані положення Плану заходів щодо реалізації Концепції розвитку цифрової економіки та суспільства України на 2018-2020 рр. [1], заплановані на I квартал 2018 р, щодо: 1) визначення індексів, індикаторів та методик оцінювання цифрового розвитку України відповідно до міжнародних практик, 2) забезпечення проведення регулярних оцінювань цифрового розвитку та визначення прогнозних показників цифрового розвитку України до 2020 р., 3) визначення та запровадження статистичної методології та статистичних спостережень для отримання статистичних даних щодо цифрового розвитку. України з урахуванням міжнародних практик. Офіційна статистика сфери в Україні користується застарілими підходами. Це утруднює міжнародні порівняння стану розвитку сфери та формування орієнтирів іiі розвитку. Досі не розроблено Національний план розвитку ШСД в Україні.

Україна підписала Угоду про Асоціацію з $€$, тому логічно намагатися перейти на статистичні стандарти обліку ШСД ЄС за показниками DESI (Digital Economy and Society Index) в частині ШСД (становлять його $15 \%$ ) [2]. Однак, цьому заважає ряд методологічних і методичних розбіжностей між підходами офіційної статистики ШСД в Україні і підходами ЄС. Для їх зняття, потрібний їх аналіз і адаптація. Інакше сатистична картина ШСД в Україні не буде релевантною, що небезпечно для перспектив економічного і технологічного зростання країни. Доцільні для наслідування й підходи інших міжнародних організацій в цій сфері.

Аналіз останніх досліджень і публікацій. Цій важливій проблемі присвячено ряд публікацій Европейської комісії [2], Міжнародного союзу електрозв’язку (МСЕ) [3], Комісії ООН 3 широкосмугового зв'язку [4], урядових рішень, таких як Концепції розвитку цифрової економіки та суспільства України на 20182020 pp. [1] та інших.

Мета статті. Визначити методологічні розбіжності підходів офіційної статистики ШСД в Україні від підходів $Є С$ (Єврокомісії, Євростату) та інших міжнародних організацій, що опікуються сферою ШСД, запропонувати шляхи їх елемінування та нові підходи до формування статистики сфери у країні, що розвивається.

\section{РЕЗУЛЬТАТИ ДОСЛІДЖЕННЯ}

Натепер більшість країн реалізує стратегії розвитку оптичних мереж ШСД і використовує для моніторингу цього процесу, планування розвитку сфери індикатор частки підключення населення до мережі f-ШСД на обумовлених швидкостях. В ЄС у 2018 р. f-ШСД користувалися $98 \%$ домогосподарств, $76 \%$ з них мали високошвидкісний f-ШСД зі швидкістю вище 30 Мбіт/с. ЄС планує забезпечити 100 \% населення можливістю під'єднання на швидкості від 30 Мбіт/с та 50 \% населення на швидкості від 100 Мбіт/с до 2020 р. [3], керуючись відповідними Національними планами ШСД. За даними MCE, у 2018 р. 62,7 \% з 193-х його країн-членів натепер впроваджують Національні стратегії (плани) розвитку ШСД; 2,1 \% їх розробляють; 35,7 \% їх не мають, в тому числі Україна.

Показники DESI в частині ШСД подані в табл. 1.

MCE визначає нижню межу швидкості ШСД в 256 кбіт/с. В Україні не існує чіткого законодавчого визначення параметрів ШСД. Національна комісія, що здійснює державне регулювання у сфері зв'язку та інформатизації (НКРЗІ) вважає ШСД доступ до мережі Інтернет зі швидкістю від 2 Мбіт/с, керуючись лише принципом його дуплексності [5].

Держстат на офіційному сайті оприлюднює дані по кількості усіх і домашніх абонентів ШСД зі швидкістю 10-100 Мбіт/с разом для f-ШСД та для m-ШСД зі швидкістю 256 Кбіт/с - 10 Мбіт/с та 10-100 Мбіт/с і не більше (табл. 2).

В той час як форма Державного статистичного спостереження № 14 (зв'язок- квартальна) [7] вимагає від підприємств подачі показників ШСД зі швидкістю 100 Мбіт/с - 1 Гбіт/с та вище 1 Гбіт/с для f- i m-ШСД, проте вони не публікуються (табл. 3). Окремо не передбачений діапазон спостережень швидкості від $30 \mathrm{Mбiт/с} \mathrm{(практика} € C)$. 
ПОКАЗНИКИ ШСД ЗА ІНДЕКСОМ DESI [2]

\begin{tabular}{|c|c|c|c|}
\hline Підмасив & Індикатор & Опис & од. виміру \\
\hline \multirow{2}{*}{$\begin{array}{l}\text { la. } \\
\text { f-ШСД }\end{array}$} & 1a1. Покриття f-ШСД & $\begin{array}{l}\text { \% домогосподарств, охоплених f-ШСД за технологіями: } \\
\text { xDSL, кабель (основний та NGA), FTTP або мережі WiMax }\end{array}$ & $\begin{array}{c}\% \text { домо- } \\
\text { господарств }\end{array}$ \\
\hline & $\begin{array}{l}\text { 1a2. Підписка } \\
\text { домогосподарств } \\
\text { на f-ШСД }\end{array}$ & $\begin{array}{l}\text { \% домогосподарств-підписчиків f-ШСД за технологіями: } \\
\text { xDSL, кабель (основний та NGA), FTTP або мережі WiMax }\end{array}$ & $\begin{array}{c}\% \text { домо- } \\
\text { господарств }\end{array}$ \\
\hline \multirow{3}{*}{$\begin{array}{l}\text { 1b. } \\
\text { m-ШСД }\end{array}$} & 1b1. Покриття $4 \mathrm{G}^{\star}$ & $\begin{array}{l}\text { \% населення, охопленого 4G-покриттям в середньому } \\
\text { операторами телекомунікацій в країні }\end{array}$ & $\begin{array}{c}\% \text { домо- } \\
\text { господарств }\end{array}$ \\
\hline & $\begin{array}{l}\text { 1b2. Підписка } \\
\text { на m-ШСД }\end{array}$ & кількість підписок на 100 ос. населення & $\begin{array}{l}\text { Підписка } \\
\text { на } 100 \text { ос. } \\
\text { населення }\end{array}$ \\
\hline & 1b3. Spectrum ${ }^{* *}$ & $\begin{array}{l}\text { виконання необхідних заходів для та використання } \\
\text { необхідного для надання послуги т-ШСД РЧР }\end{array}$ & \% від цілі \\
\hline \multirow{2}{*}{$\begin{array}{l}\text { 1c. } \\
\text { Швид- } \\
\text { кий } \\
\text { ШСД }\end{array}$} & $\begin{array}{l}\text { 1c1. Охоплення } \\
\text { швидким ШСД }\end{array}$ & $\begin{array}{l}\text { \% домогосподарств, охоплених ШСД швидкістю } \\
\text { завантаження від } 30 \text { Мбіт/с за технологіями: FTTH, FTTB, } \\
\text { кабелі DOCSIS } 3.0 \text { і VDSL }\end{array}$ & $\begin{array}{c}\% \text { домо- } \\
\text { господарств }\end{array}$ \\
\hline & $\begin{array}{l}\text { 1c2. Підписка } \\
\text { на швидкий ШСД }\end{array}$ & $\begin{array}{l}\text { \% домогосподарств, охоплених ШСД зі швидкістю вище } \\
30 \text { Мбіт/с }\end{array}$ & $\begin{array}{c}\% \text { домо- } \\
\text { господарств }\end{array}$ \\
\hline \multirow{2}{*}{$\begin{array}{c}\mathbf{1 d .} \\
\text { Над- } \\
\text { швид- } \\
\text { кий } \\
\text { ШСД }\end{array}$} & $\begin{array}{l}\text { 1d1. Надшвидкий } \\
\text { ШСД, охоплення }\end{array}$ & $\begin{array}{l}\text { \% домогосподарств, охоплених ШСД зі швидкістю заван- } \\
\text { таження вище } 100 \text { Mбiт/c (NGA) за технологіями FTTH, } \\
\text { FTTB, кабелі DOCSIS } 3.0\end{array}$ & $\begin{array}{c}\% \text { домо- } \\
\text { господарств }\end{array}$ \\
\hline & $\begin{array}{l}\text { 1d2. Надшвидкий } \\
\text { ШСД, підписка }\end{array}$ & $\begin{array}{l}\text { \% домогосподарств-підписчиків ШСД зі швидкістю } \\
\text { вище } 100 \text { Мбіт/с (NGA) }\end{array}$ & $\begin{array}{c}\% \text { домо- } \\
\text { господарств }\end{array}$ \\
\hline $\begin{array}{l}\text { 1е. } \\
\text { Індекс } \\
\text { цін } \\
\text { ШСД }\end{array}$ & 1e1. Індекс цін ШСД & $\begin{array}{l}\text { ціни } 12 \text { кошиків послуг у базовому кошику ШСД, \% } \\
\text { в доході домогосподарств за ПКС. Кошики включають } \\
3 \text { категорії швидкості (12-30 Мбіт/с, 30-100 Мбіт/с та від } \\
100 \text { Мбіт/с) та } 4 \text { типи продуктів (автономний Інтернет, } \\
\text { Інтернет + телебачення (ТБ), Інтернет + фіксована теле- } \\
\text { фонія та Інтернет + ТБ + фіксована телефонія). }\end{array}$ & $\begin{array}{l}\text { Шкала } \\
(0-100)\end{array}$ \\
\hline
\end{tabular}

Примітки

* 4G - технології зв'язку, що дозволяють здійснювати передачу даних зі швидкістю вище 100 Мбіт/с рухомим і 1 Гбіт/с - стаціонарним абонентам: LTE Advanced (LTE-A) i WiMAX 2 (WMAN- Advanced, IEEE $802.16 \mathrm{~m}$ ) офіційно визнані бездротовими стандартами зв'язку 4G (IMT-Advanced) MCE на конференції в Женеві в 2012 p.

** — показник не розраховується в ЄС з 2018 р.

Абревіатури: NGA (next-generation access) - мережі доступу нового покоління, xDSL (Digital Subscribe Line) - цифрова абонентська лінія, DOCSIS 3.0 (Over Cable Service Interface Specifications - стандарт передачі даних по коаксіальному (телевізійному) кабелю), VDSL (Very high speed Digital Subscriber Line) супершвидкісна цифрова абонентська лінія, FTTx (Fiber to the x) - оптоволокно до: Н (home) 一 до будинку, B (building) - до межі будівлі, P (premises) - приміщення (разом Н і В); ПКС - паритет купівельної спроможності, РЧР - радіочастотний ресурс, ТБ - телебачення.

У підсумку не ідентифікованими щодо того, чи вони отримують ШСД зі швидкістю меншою або більшою від зазначеного Держстатом діапазону, є 34,0 \% абонентів f-ШСД: 32,1 \% - домашні, 60,1 \% - інші; для т-ШСД - 7,8 \% абонентів: 7,8 \% - домашні, 8,1 \% - інші (табл. 2). Через це в статистиці міжнародних організацій, таких як MCE, не ідентифікується ціна послуги
f-ШСД в Україні залежно від їх швидкості. Також складно встановити обсяг трафіку за підпискою на місяць (рис. 1).

3 табл. 3 також випливає відмінність в термінології технологій і способів підключення ШСД від DESI, не дивлячись на їх методологічну близькість до показників технологій підключення: FTTH, FTTB, FTTP, кабелі DOCSIS 3.0 i VDSL. 
КІЛЬКІСТЬ АБОНЕНТІВ ПОСЛУГ ТЕЛЕКОМУНІКАЦІЙ В УКРАЇНІ В 2018 р., тис. * [6]

\begin{tabular}{|c|c|c|c|c|c|c|c|c|}
\hline & \multirow{2}{*}{ Усього } & \multicolumn{2}{|c|}{ У т.ч.: } & \multicolumn{2}{|c|}{$\begin{array}{c}\text { \% до загалу } \\
\text { (рядок) }\end{array}$} & \multicolumn{3}{|c|}{$\begin{array}{l}\text { \% до загалу } \\
\text { (стовбчик) }\end{array}$} \\
\hline & & домашні & інші & домашні & інші & yci & домашні & інші \\
\hline Кількість абонентів т-зв'язку & 53933,6 & 49302,8 & 4630,8 & 91,4 & 8,6 & 100 & 100 & 100 \\
\hline $\begin{array}{l}\text { Кількість абонентів Інтернет, } \\
\text { у т.ч.: }\end{array}$ & 26066,8 & 23354,2 & 2712,6 & 89,6 & 10,4 & 100 & 100 & 100 \\
\hline в сільській місцевості & 652,9 & 629,5 & 23,4 & 96,4 & 3,6 & 2,5 & 2,7 & 0,9 \\
\hline $\begin{array}{l}\text { із загальної кількості абонентів } \\
\text { Інтернет - з ШСД, у т.ч.: }\end{array}$ & 25312,7 & 22861,1 & 2451,6 & 90,3 & 9,7 & 97,1 & 97,9 & 90,4 \\
\hline f-, з них зі швидкістю: & 5288,3 & 4936,2 & 352,1 & 93,3 & 6,7 & 20,9 & 20,9 & 21,6 \\
\hline 10-100 Мбіт/с & 3492,5 & 3351,9 & 140,6 & 96,0 & 4,0 & 66,0 & 66,0 & 67,9 \\
\hline інша & 1795,8 & 1584.3 & 211,5 & 88,2 & 13,3 & 34,0 & 32,1 & 60,1 \\
\hline m-, 3 них: & 20024,4 & 17924,9 & 2099,5 & 89,5 & 10,5 & 79,1 & 79,1 & 78,4 \\
\hline у \% від абонентів m-зв’язку & & & & & & 37,1 & 37,1 & 36,4 \\
\hline з них зі швидкістю: & & & & & & & & \\
\hline 256 Кбіт/с - 10 Мбіт/с & 15193,9 & 13418,0 & 1775,9 & 88,3 & 11,7 & 75,9 & 75,9 & 74,9 \\
\hline 10-100 Мбіт/с & 3267,1 & 3046,9 & 220,2 & 93,3 & 6,7 & 16,3 & 16,3 & 17,0 \\
\hline інша & 1563,4 & 1460 & 103,4 & 93,4 & 6,6 & 7,8 & 7,8 & 8,1 \\
\hline
\end{tabular}

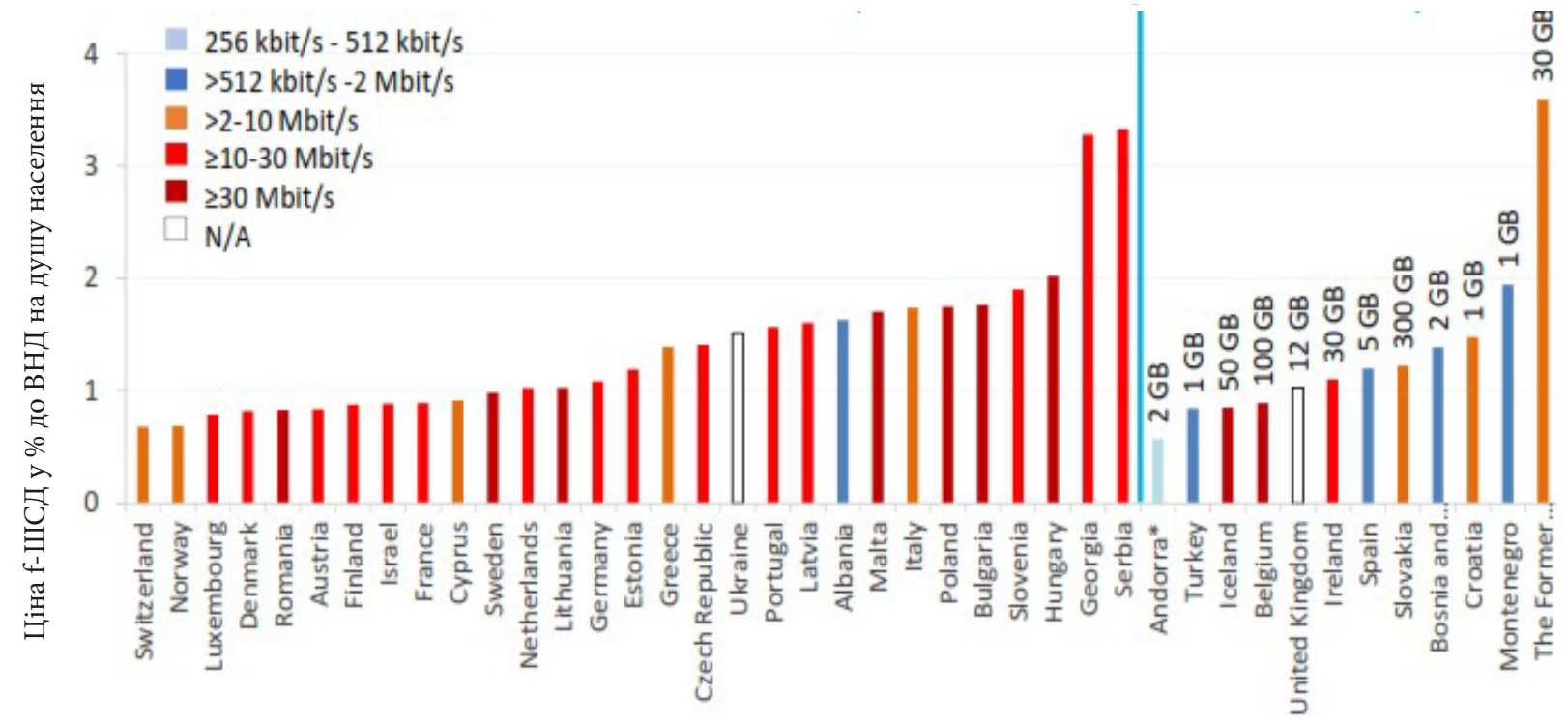

Рuc. 1. Ціни послуг f-ШСД у \% до ВНД на душу населення (д.н.) в країнах Європи, швидкості, обмеження обсягу трафіку * [3]

* Примітка. Швидкість та обмеження на місяць стосуються рекламованої швидкості та кількості даних, включених до передплати f-ШСД початкового рівня. 


\section{ПОКАЗНИКИ, ЯКІ ДЕРЖСТАТ ВИМАГАЄ ВІД ОПЕРАТОРІВ І ПРОВАЙДЕРІВ ТЕЛЕКОМУНІКАЦІЙНИХ ПОСЛУГ ЗГІДНО ФОРМИ ДЕРЖАВНОГО СТАТСПОСТЕРЕЖЕННЯ № 14 (ЗВ’ЯЗОК-КВАРТАЛЬНА) ЩОДО ШСД [7]}

\begin{tabular}{|c|c|}
\hline f-ШСД, з нього: & m-ШСД, з нього: \\
\hline за технологіями підключення, у т.ч.: & у т.ч. за способом підключення \\
\hline цифрова абонентська лінія & стандартний \\
\hline \multirow{2}{*}{$\begin{array}{l}\text { волоконно-оптичне підключення до } \\
\text { будинку/оселі }\end{array}$} & спеціалізований \\
\hline & за технологією підключення, у т.ч.: \\
\hline $\begin{array}{l}\text { волоконно-оптичне підключення до } \\
\text { розподільчої шафи }\end{array}$ & $\begin{array}{l}\text { HSPA + (HSDPA + HSUPA + HSPA Evolved }) \\
\text { HSPA + (4G) }\end{array}$ \\
\hline локальна мережа (Ethernet To The Home) & WCDMA, UMTS \\
\hline $\begin{array}{l}\text { модемне підключення до мереж кабельного } \\
\text { телебачення }\end{array}$ & $\begin{array}{l}\text { CDMA2000 (1xEV-DO, EV-DO Rev.A, EV-DO } \\
\text { Rev.B тощо), WiMAX 802.16e }\end{array}$ \\
\hline інші & LTE \\
\hline зі швидкістю доступу, у т.ч.: & фіксовані безпроводові канали зв'язку, у т.ч.: \\
\hline від 256 Кбіт/с до 2 Мбіт/с & $\mathrm{Wi}-\mathrm{Fi}$ \\
\hline від 2 Мбіт/с до 10 Мбіт/с & WiMax \\
\hline від 10 Мбіт/с до 100 Мбіт/с & інші \\
\hline від 100 Мбіт/с до 1 Гбіт/с & супутникові канали зв’язку \\
\hline \multirow[t]{6}{*}{ понад 1 Гбіт/с } & зі швидкістю доступу, у т.ч.: \\
\hline & від 256 Кбіт/с до 2 Мбіт/с \\
\hline & від 2 Мбіт/с до 10 Мбіт/с \\
\hline & від 10 Мбіт/с до 100 Мбіт/с \\
\hline & від 100 Мбіт/с до 1 Гбіт/с \\
\hline & понад 1 Гбіт/с \\
\hline
\end{tabular}

Підходи України і ЄС також розрізняються реєстрацією об’єкта підписки ШСД: в Україні - абонент, в ЄC - домогосподарство. При цьому неможливо знехтувати відмінностями цих понять, оскільки домогосподарство (маєток, велике домо- чи землеволодіння тощо) може мати декілька точок доступу, тоді як декілька домогосподарств можуть мати одну спільну точку доступу (наприклад, Wi-Fi на поверсі гуртожитку). Адже офіційна статистика керується визначенням інституційного домогосподарства згідно Закону України «Про Всеукраїнський перепис населення», як сукупності осіб, що спільно проживають в одному житловому приміщенні (його частині), забезпечують себе всім необхідним для життя, ведуть спільне господарство, повністю (частково) об’єднють та витрачають кошти, ці особи мо- жуть перебувати в родинних стосунках (свояцтва), не перебувати у будь-яких з цих стосунків, або бути і в тих, і в інших стосунках, домогосподарство може складатися з однієї особи. Абонент не завжди підпадає під ці визначення. Держстат здійснює вибіркові обстеження умов життя домогосподарств, яке відповідає міжнародним стандартам В обстеженні беруть участь мешканці усіх типів гуртожитків (сімейних, студентських тощо). Через зазначене Держстатистика іноді використовує термін «неінституційне домогосподарство». Тому не можна співставляти показники показники охоплення ШСД в ЄС та Україні. 3 урахуванням особливостей обліку ШСД Держстатом, спробуємо проаналізувати тотожність показника 1a f-ШСД (підписка домогосподарств), виходячи з даних табл. 2 та даних щодо кількості домо- 
господарств за цей період (14934,9 тис. од.[8]). Чи можливо ототожнити поняття «домашній абонент» $\mathrm{i}$ «домогосподарство»? За логікою до складу недомашніх абонентів ШСД входять бізнес-, державні і громадські користувачі, проте частина приватних підприємців і фізосіб-підприємців може працювати в рамках домогосподарств, користуючись послугами f-ШСД. Тобто методологія підрахунку показника DESI 1a f-ШСД та 1a m-ШСД (підписка на m-ШСД домогосподарств) і практики Держстату сутнісно різні.

Крім того, необхідне чітке розуміння терміну «підписка», яким оперує DESI. Як підключення після укладання контракту на f-ШСД з певним тарифним планом (кошик) між абонентом та надавачем послуги, з ідентифікацією абонента через місце отримання послуги, умови надання послуг - швидкість, термін, пакетність, деталізацію (кількість точок доступу, спосіб оплати (предоплата або післяплата prepaid або postpaid), тип точок доступу (модем, роутер, Wi-Fi тощо). Через це всі абоненти f-ШСД можуть вважатися підписчиками. Їх кількість та частка в загалі подана в табл. 4. Англійською поняття «абонет» та «підписчик» перекладаються онаково (subscriber), проте сутнісні відмінності між ними $\epsilon$, тому офіційна статистика України не застосовує поняття «підписка», натомість використовуючи поняття «абонент».

В Україні підключення абонентів до послуг m-ШСД може здійснюватися з оплатою за контрактом (можливо 3 післяплатою) з ідентифікацію абонента, або з попередньою оплатою (prepaid) (після анонімної купівлі SIM-карти, що зберігає лише ідентифікаційну інформацію про акаунт, який анонімно поповнюється). Незважаючи на гірший рівень захисту таких абонентів в базах найбільших компаній «Київстар», «Vodafone Україна» i lifecell таких більше 90 \%. За даними MCE в 2016 р. на ринках країн, що розвиваються, в оплаті послуг $\mathrm{m}$-зв'язку домінувала prepaid-підписка.

За методологією Євростату показник «кількість т-підписок» відображає число підписок на системи рухомого зв'язку. Активні передплачені карти також розглядаються як підписки, одна людина може мати більше однієї підписки [9]. В ЕС також розповсюджена практика купівлі одноразових передплатних SIM-карт, наприклад, туристичних, як TravelSiM, GlobalSIM, Simfortour, ГудЛайн тощо, які лише в певний проміжок часу є активними, тому практика такого підрахунку підписчиків викликає сумніви. Проте за цією логікою усіх передплатних користувачів також можна вважати підписчиками.

Таблиия 4

КІЛЬКІСТЬ АБОНЕНТІВ ІНТЕРНЕТ 3 НАДАННЯМ ШСД ЗА РЕГІОНАМИ І ТИПОМ ПОСЛУГ У 2018 р. [6]

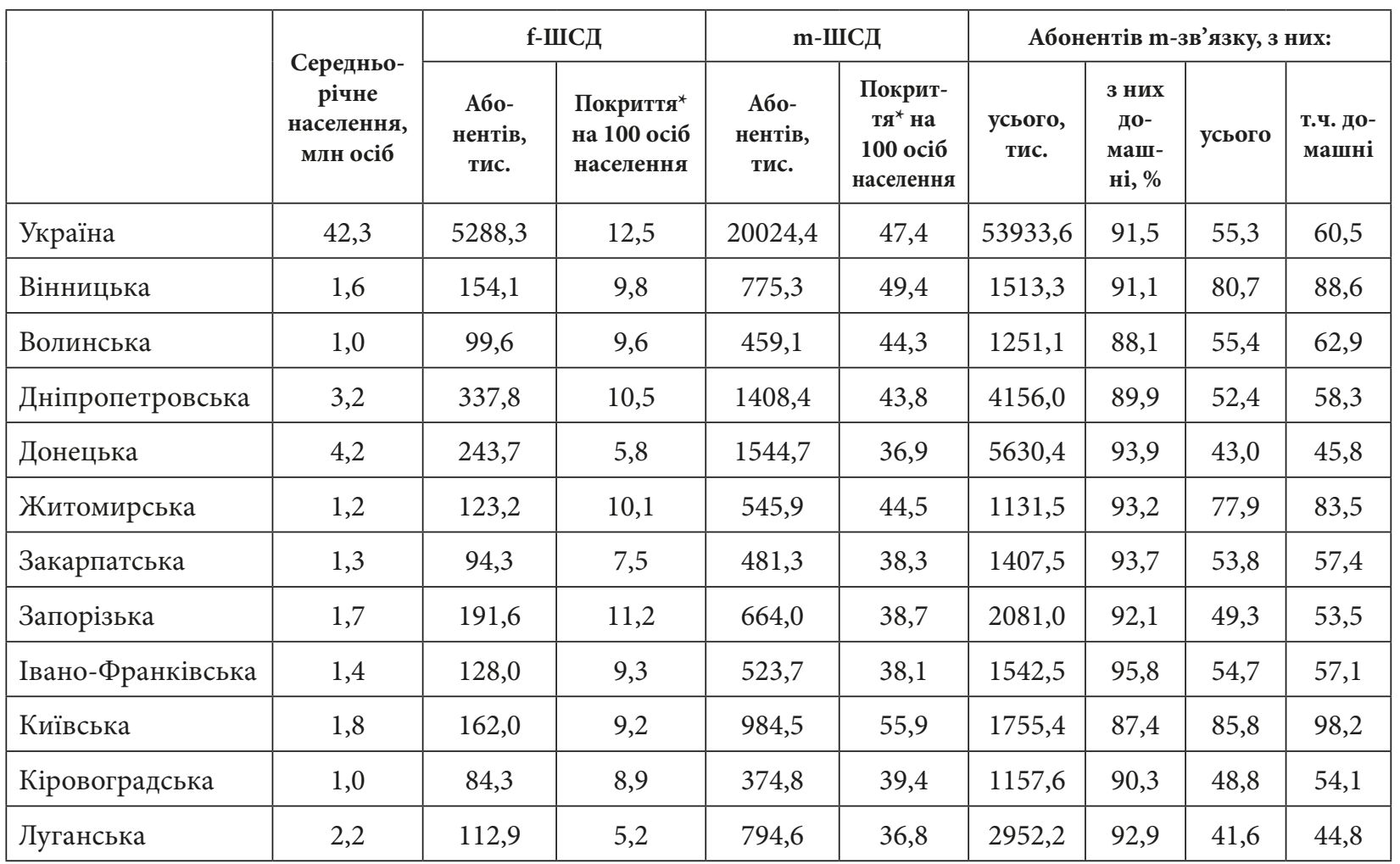


Таблиия 4 (продовж.)

\begin{tabular}{|c|c|c|c|c|c|c|c|c|c|}
\hline & \multirow{2}{*}{$\begin{array}{l}\text { Середньо- } \\
\text { річне } \\
\text { населення, } \\
\text { млн осіб }\end{array}$} & \multicolumn{2}{|c|}{ f-ШСД } & \multicolumn{2}{|c|}{ m-ШСД } & \multicolumn{4}{|c|}{ Абонентів m-зв'язку, з них: } \\
\hline & & $\begin{array}{c}\text { Або- } \\
\text { нентів, } \\
\text { тис. }\end{array}$ & $\begin{array}{l}\text { Покриття* } \\
\text { на } 100 \text { осіб } \\
\text { населення }\end{array}$ & $\begin{array}{c}\text { Або- } \\
\text { нентів, } \\
\text { тис. }\end{array}$ & $\begin{array}{c}\text { Покрит- } \\
\text { тя* на } \\
100 \text { осіб } \\
\text { населення }\end{array}$ & $\begin{array}{l}\text { усього, } \\
\text { тис. }\end{array}$ & $\begin{array}{c}\text { з них } \\
\text { до- } \\
\text { маш- } \\
\text { ні, \% }\end{array}$ & усього & $\begin{array}{l}\text { т.ч. до- } \\
\text { машні }\end{array}$ \\
\hline Львівська & 2,5 & 279,8 & 11,1 & 1308,5 & 51,8 & 2768,1 & 88,8 & 72,7 & 81,9 \\
\hline Миколаївська & 1,1 & 186,3 & 16,4 & 582,2 & 51,2 & 1586,4 & 91,7 & 56,9 & 62,1 \\
\hline Одеська & 2,4 & 298,6 & 12,5 & 2311,3 & 97,0 & 3382,9 & 90,5 & 58,2 & 64,3 \\
\hline Полтавська & 1,4 & 171,0 & 12,2 & 564,1 & 40,1 & 1921,4 & 95,2 & 46,2 & 48,5 \\
\hline Рівненська & 1,2 & 97,3 & 8,4 & 481,7 & 41,6 & 1130,8 & 93,7 & 68,4 & 73,0 \\
\hline Сумська & 1,1 & 104,6 & 9,6 & 434,7 & 40,0 & 1462,5 & 91,1 & 45,4 & 49,8 \\
\hline Тернопільська & 1,0 & 100,4 & 9,6 & 405,5 & 38,7 & 873,2 & 88,4 & 69,9 & 79,2 \\
\hline Харківська & 2,7 & 246,3 & 9,2 & 1276,7 & 47,6 & 3998,7 & 92,3 & 49,9 & 54,1 \\
\hline Херсонська & 1,0 & 104,0 & 10,0 & 420,5 & 40,3 & 1534,4 & 95,8 & 42,7 & 44,6 \\
\hline Хмельницька & 1,3 & 126,3 & 9,9 & 515,1 & 40,6 & 1013,8 & 90,0 & 80,5 & 89,4 \\
\hline Черкаська & 1,2 & 102,6 & 8,5 & 565,3 & 46,6 & 1263,5 & 88,3 & 68,2 & 77,2 \\
\hline Чернівецька & 0,9 & 84,5 & 9,3 & 331,7 & 36,6 & 1101,6 & 94,1 & 47,2 & 50,2 \\
\hline Чернігівська & 1,0 & 109,3 & 10,8 & 533,5 & 52,7 & 1305,4 & 91,4 & 64,4 & 70,5 \\
\hline м. Київ & 2,9 & 1545,8 & 52,5 & 1737,3 & 59,0 & 6012,4 & 86,2 & 48,2 & 55,9 \\
\hline
\end{tabular}

* Примітка. Показник не сумісний з показником DESI.

Таким чином складається дивна ситуація, що з зарубіжної статистики можна отримати дані, недоступні в офіційній статистиці України (табл. 6).

Таблиия 6

КЛЮЧОВІ ІНДИКАТОРИ РОЗВИТКУ ІКТ ЗА ВЕРСІЄЮ ІTU В 2016 р. [10]

\begin{tabular}{|l|c|c|c|c|}
\hline \multicolumn{1}{|c|}{ Ключові індикатори 2016 p. } & україна & Білорусія & СНд & Світ \\
\hline Мобільний стільниковий зв’язок, підписка на 100 жителів & 132,6 & 124,2 & 141,2 & 101,5 \\
\hline F-ШСД, підписка на 100 жителів & 12,0 & 33,3 & 15,8 & 12,4 \\
\hline Активний m-ШСД, підписка на 100 жителів & 22,6 & 69,5 & 59,7 & 52,2 \\
\hline Покриття 3G, \% населення & 90,0 & 98,7 & 77,1 & 85,0 \\
\hline Покриття LTЕ / WіМАХ, \% населення & 1,4 & 41,5 & 45,9 & 66,5 \\
\hline Ціни т-стільникового зв’язку, \% доходу домогосподарств, ПКС) & 1,2 & 1,1 & 1,7 & 5,2 \\
\hline Ціни f-ШСД, \% доходу домогосподарств, ПКС & 1,1 & 1,2 & 3,3 & 13,9 \\
\hline Ціни т-ШСД 500 Мб, \% доходу домогосподарств, ПКС & 1,2 & 0,6 & 1,4 & 3,7 \\
\hline Ціни т-ШСД 1 Гб, \% доходу домогосподарств, ПКС & 0,9 & 1,1 & 3,1 & 6,8 \\
\hline Відсоток домогосподарств з комп’ютером & 65,1 & 67,0 & 67,4 & 46,6 \\
\hline Відсоток домогосподарств з доступом до Інтернету & 54,8 & 62,5 & 68,0 & 51,5 \\
\hline Відсоток осіб, що використовують Інтернет & 52,5 & 71,1 & 65,1 & 45,9 \\
\hline Сукупна пропускна здатність Інтернет для користувача, Кбіт/с & 79,9 & 168,5 & 59,0 & 74,5 \\
\hline
\end{tabular}


МСЕ узагальнює дані приватних операторів та провайдерів щодо цін кошиків послуг, які включають ШСД, кошики МСЕ відрізняються від кошиків DESI (табл. 7, 8), тому ці дані по Україні неможливо порівнювати з показниками ЄС.

Таблиці 7

ЦІНИ РІЗНИХ КОШИКІВ М-ШСД У 2017 р. У ПОСТРАДЯНСЬКИХ КРАЇНАХ [3]

\begin{tabular}{|c|c|c|c|c|c|c|c|}
\hline Ранг & Країна & $\begin{array}{c}\% \text { від ВНД } \\
\text { на д.н. }\end{array}$ & $\$$ & ПКС, \$ & $\begin{array}{c}\text { Доступний } \\
\text { місячний } \\
\text { обсяг даних }\end{array}$ & $\begin{array}{c}\text { Включена } \\
\text { в ціну ставка } \\
\text { податку, \% }\end{array}$ & $\begin{array}{c}\text { ВНД } \\
\text { на д.н., } \$^{*}\end{array}$ \\
\hline \multicolumn{8}{|c|}{ prepaid на основі телефону за 500 Мб } \\
\hline 6 & Естонія & 0,15 & 2.25 & 3.30 & $500 \mathrm{Mб}$ & 20.0 & 18190 \\
\hline 11 & Литва & 0,27 & 3.38 & 5.84 & 1536 Мб & 21.0 & 15200 \\
\hline 20 & Латвія & 0,37 & 4.49 & 6.92 & $600 \mathrm{M6}$ & 21.0 & 14740 \\
\hline 21 & Грузія & 0,38 & 1.20 & 3.52 & 500 Мб & 21.0 & 3790 \\
\hline 22 & Бєларусь & 0,38 & 1.68 & 6.70 & 500 Мб & 25.0 & 5280 \\
\hline 26 & Російська Федерація & 0,45 & 3.43 & 8.04 & 2250 Мб & 18.0 & 9,232 \\
\hline 39 & Азербайджан & 0,51 & 1.74 & 7.92 & 500 Мб & 18.0 & 4080 \\
\hline 54 & Казахстан & 0,70 & 4.57 & 13.09 & 500 Мб & 12.0 & 7890 \\
\hline 63 & Україна & 0,85 & 1.69 & 7.61 & 500 Мб & $20.0^{\star}$ & 2388 \\
\hline 66 & Вірменія & 0,93 & 3.11 & 7.62 & 1000 Мб & 20.0 & 4000 \\
\hline 73 & Киргизтан & 1,08 & 1.02 & 3.38 & 500 Мб & 17.0 & 1,130 \\
\hline 80 & Молдова & 1,19 & 2.16 & 5.84 & 500 Мб & 20.0 & 2180 \\
\hline 96 & Туркменістан & 1,55 & 8.57 & $\ldots$ & $500 \mathrm{M6}$ & 15.0 & 6650 \\
\hline 128 & Узбекистан & 3,19 & 5.27 & $\ldots$ & $500 \mathrm{M6}$ & 20.0 & 1980 \\
\hline 145 & Таджикистан & 4,96 & 4.09 & 15.01 & 1500 Мб & 23.0 & 990 \\
\hline \multicolumn{8}{|c|}{ postpaid на основі комп’ютера за 1 ГБ } \\
\hline 27 & Естонія & 0.59 & 9.00 & 13.19 & 2 ГБ & 20.0 & 18190 \\
\hline 31 & Грузія & 0.64 & 2.02 & 5.94 & 1 ГБ & 21.0 & 3790 \\
\hline 36 & Азербайджан & 0.68 & 2.32 & 10.55 & 1 ГБ & 18.0 & 4080 \\
\hline 38 & Казахстан & 0.70 & 4.57 & 13.09 & 5 ГБ & 12.0 & 7890 \\
\hline 39 & Литва & 0.70 & 8.90 & 15.38 & 50 ГБ & 21.0 & 15200 \\
\hline 43 & Російська Федерація & 0.78 & 6.00 & 14.07 & 3 ГБ & 18.0 & 9232 \\
\hline 50 & Латвія & 0.92 & 11.27 & 17.38 & 15 ГБ & 21.0 & 14740 \\
\hline 51 & Бєларусь & 0.93 & 4.09 & 16.28 & 4 ГБ & 25.0 & 5280 \\
\hline 52 & Україна & 0.94 & 1.88 & 8.46 & 2 ГБ & $20.0^{*}$ & 2388 \\
\hline 93 & Вірменія & 2.18 & 7.25 & 17.78 & 15 ГБ & 20.0 & 4000 \\
\hline 105 & Туркменістан & 2.84 & 15.71 & $\ldots$ & 1 ГБ & 15.0 & 6650 \\
\hline 114 & Молдова & 3.57 & 6.49 & 17.52 & 10 ГБ & 16.7 & 2180 \\
\hline 121 & Киргизтан & 4.63 & 4.36 & 14.49 & $1 \Gamma Б$ & 17.0 & 1130 \\
\hline 126 & Таджикистан & 4.96 & 4.09 & 15.01 & $1 \Gamma Б$ & 23.0 & 990 \\
\hline 161 & Узбекистан & 15.97 & 26.35 & $\ldots$ & 1 ГБ & 20.0 & 1980 \\
\hline
\end{tabular}

* Примітка: в Україні до тарифу на мобільний зв’язок додатково входить збір у 7,5 \% до Пенсійного фонду.

Абревіатури: ВНД - валовий національний дохід, ПКС - паритет купівельної спроможності. 
За даними MCE, у 2017 р. майже у всіх розвинених країнах ціни на послуги $\mathrm{m}$ - ШПД на базі комп'ютера, становили менше 2 \% ВНД на душу населення (д.н.), що відповідає цільовим показникам на 2025 р., встановленим Комісією з ШСД ООН, розрахованих за методологією MCE. Це може стати оптимальним напрямком забезпечення за ціною доступу в Інтернет всіх, якщо оператори в країнах зможуть підтримувати поточний рівень цін, продовжуючи поступово збільшувати граничні обсяги даних, раз українська держава не встановлює подібних орієнтирів.

Звертають на себе увагу значні податкові послаблення у ряді країн на споживання послуг m-ШСД prepaid на основі телефону і postpaid на основі комп'ютера. В Макао, Гонконзі,
Катарі, ОАЕ вони не оподатковуються, оподатковуються за низькими ставками - в КНР (6 \%), Сингапурі (7 \%), Швейцарії (8 \%), США $(8,9 \%)$, Панамі (7 \%). Значно оподатковується m-ШСД в Бразилії (40,2 \%), ряді країн, що розвиваються.

За даними MCE, в 2017 р. Україна за ціною кошика послуг m-ШСД prepaid на основі телефону за 500 Мб трафіку посіла 63-тє місце 3 показником 0,85 \% ВНД на д.н. (\$1,69 або $\$ 7,61$ за ПКС) і 52-ге за кошиком postpaid на

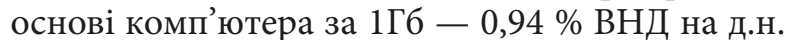
(\$1,88 або \$8,46 за ПКС) з 183-х країн (табл. 7). В 2017 р. Україна за ціною безлімітного кошика послуг f-ШСД зайняла 52-ге місце з 186-ти 3 країн з показником 1,51 \% ВНД на д.н. $(\$ 3,01)$ (табл. 8).

Таблиия 8

ЦІНА КОШИКА ПОСЛУГ Ғ-ШСД У 2017 р. РЯДУ ПОСТРАДЯНСЬКИХ КРАЇНАХ [3]*

\begin{tabular}{|c|c|c|c|c|c|c|c|c|}
\hline Ранг & Країна & $\begin{array}{l}\text { \% ВНД } \\
\text { на д.н. }\end{array}$ & $\$$ & $\begin{array}{c}\text { ПКС, } \\
\$\end{array}$ & $\begin{array}{c}\text { Швидкість, } \\
\text { Мбіт/с }\end{array}$ & $\begin{array}{c}\text { Доступний } \\
\text { місячний обсяг } \\
\text { даних, Гб }\end{array}$ & $\begin{array}{c}\text { Включена } \\
\text { вціну ставка } \\
\text { податку, \% }\end{array}$ & $\begin{array}{c}\text { ВНД } \\
\text { на д.н., } \\
\quad \$\end{array}$ \\
\hline 4 & Російська Федерація & 0.45 & 3.43 & 8.04 & 30.0 & Безліміт & 18 & 9232 \\
\hline 23 & Казахстан & 0.90 & 5.92 & 16.95 & 1.0 & 10.0 & 12 & 7890 \\
\hline 28 & Бєларусь & 1.02 & 4.50 & 17.93 & & 10.0 & 25 & 5280 \\
\hline 30 & Литва & 1.03 & 13.03 & 22.50 & 100.0 & Безліміт & 21 & 15200 \\
\hline 36 & Естонія & 1.19 & 18.03 & 26.41 & 10.0 & Безліміт & 20 & 18190 \\
\hline 52 & Україна & 1.51 & 3.01 & $\ldots$ & 13.53 & Безліміт & $20^{*}$ & 2388 \\
\hline 57 & Латвія & 1.61 & 19.72 & 30.41 & 10.0 & Безліміт & 21 & 14740 \\
\hline 60 & Азербайджан & 1.71 & 5.81 & 26.39 & 1.0 & Безліміт & 18 & 4080 \\
\hline 77 & Узбекистан & 2.53 & 4.17 & $\ldots$ & 1.0 & 2.4 & 20 & 1980 \\
\hline 84 & Вірменія & 3.11 & 10.36 & 25.40 & 4.0 & Безліміт & 20 & 4000 \\
\hline 86 & Грузія & 3.28 & 10.36 & 30.54 & 10.0 & Безліміт & 18 & 3790 \\
\hline 93 & Туркменістан & 3.63 & 20.14 & ... & 2.0 & 1.0 & 15 & 6650 \\
\hline 11 & Молдова & 5.95 & 10.81 & 29.20 & 100.0 & Безліміт & 20 & 2180 \\
\hline 12 & Таджикистан & 8.51 & 7.02 & 25.73 & 2.0 & 15.0 & 18 & 990 \\
\hline 12 & Киргизтан & 8.88 & 8.36 & 27.82 & 0.5 & Безліміт & 12 & 1130 \\
\hline
\end{tabular}

* Примітка. В Україні до тарифу m-зв’язку додатково входить збір у 7,5% до Пенсійного фонду.

Зменшення сукупних і питомих (ARPU Average revenue per user) доходів від телекомунікаційних послуг через насичення ринку є світовою тенденцією, яку підтверджують дані MCE, хоча в розвиток сектора вкладена значна частина отриманих доходів у вигляді капітальних інвестицій (табл. 9).
Так, ПрАТ «Київстар» вклав у 4G-зв'язок 7 млрд грн у 2018 р., в 2019 планує інвестувати ще 2 млрд грн [11]. Проте такого роду дані $€$ фрагментарними, що унеможливлює аналіз ситуації в Україні. В той же час НКРЗІ, що посилається на Держстат (хоча той подає на офіційному сайті дані за 2018 р. тільки в розрізі 
f-ШСД, архів не працює), подано інформацію про доходи телекомунікаційної галузі у фактичних цінах, при цьому темпи зміни їх обся- гів, розраховуються без врахування інфляції (табл. 10), хоча за даними Держстату середньорічна інфляція в 2018 р. склала 10,9\%.

Табличяя 9

ОКРЕМІ ФІНАНСОВІ ПОКАЗНИКИ СЕКТОРУ ТЕЛЕКОМУНІКАЦІЙ РЯДУ ПОСТРАДЯНСЬКИХ КРАЇН [3]

\begin{tabular}{|c|c|c|c|c|c|c|c|}
\hline & \multicolumn{3}{|c|}{$\begin{array}{c}\text { Сукупні доходи від надання } \\
\text { телекомунікаційних послуг, \$ млн }\end{array}$} & \multirow{2}{*}{ Країни } & \multicolumn{3}{|c|}{$\begin{array}{c}\text { Сукупні доходи від надання } \\
\text { послуг m-зв'язку, \$ млн }\end{array}$} \\
\hline & 2014 & 2015 & 2016 & & 2014 & 2015 & 2016 \\
\hline Російська Федерація & 39506 & 25089 & 22778 & Російська Федерація & 18838 & 10853 & 9716 \\
\hline Узбекистан & 1362 & 1742 & 2191 & Узбекистан & 1045 & 1079 & 1357 \\
\hline Казахстан & 3799 & 3167 & 2111 & Україна & 2261 & 1266 & 1201 \\
\hline Україна & 3485 & 2033 & 1910 & Казахстан & 1565 & 1161 & 718 \\
\hline Бєларусь & 1402 & 1096 & 1084 & Бєларусь & 853 & 646 & 633 \\
\hline Азербайджан & 2185 & 1602 & 1005 & Литва & 320 & 271 & 398 \\
\hline Латвія & 702 & 597 & 798 & Латвія & 364 & 308 & 252 \\
\hline Литва & 640 & 515 & 733 & Естонія & 273 & 258 & 241 \\
\hline Естонія & 744 & 683 & 649 & Киргизтан & 345 & 293 & 239 \\
\hline Киргизтан & 519 & 418 & 368 & Вірменія & 286 & 210 & 177 \\
\hline Грузія & 420 & 311 & 310 & Грузія & 258 & 177 & 177 \\
\hline Вірменія & 382 & 316 & 288 & Молдова & 176 & 137 & 134 \\
\hline Молдова & 325 & 260 & 225 & & & & \\
\hline
\end{tabular}

\begin{tabular}{|c|c|c|c|c|c|c|c|}
\hline \multirow[t]{2}{*}{ Країни } & \multicolumn{3}{|c|}{$\begin{array}{c}\text { Капітальні інвестиції } \\
\text { в телекомунікації, \% } \\
\text { від доходу сектору, }\end{array}$} & \multirow[t]{2}{*}{ Країни } & \multicolumn{3}{|c|}{$\begin{array}{c}\text { ARPU від підписки на m-зв'я- } \\
\text { зок, \$ }\end{array}$} \\
\hline & 2014 & 2015 & 2016 & & 2014 & 2015 & 2016 \\
\hline Грузія & 25.5 & 72.7 & 47.5 & Естонія & 12.0 & 11.3 & 10.6 \\
\hline Молдова & 52.0 & 42.2 & 32.4 & Латвія & 12.7 & 9.9 & 7.9 \\
\hline Киргизтан & 15.0 & 0.6 & 26.7 & Узбекистан & 4.0 & 4.1 & 4.9 \\
\hline Вірменія & 22.1 & 22.9 & 26.3 & Бєларусь & 6.2 & 4.7 & 4.6 \\
\hline Україна & 16.1 & 50.0 & 25.8 & Азербайджан & 12.0 & 6.6 & 4.2 \\
\hline Російська Федерація & 24.5 & 23.7 & 22.0 & Російська Федерація & 7.1 & 4.0 & 3.5 \\
\hline Узбекистан & 24.3 & 20.7 & 20.7 & Молдова & 3.9 & 3.1 & 2.9 \\
\hline Литва & 17.1 & 17.0 & 20.0 & Грузія & 4.0 & 2.7 & 2.7 \\
\hline Естонія & 16.2 & 15.2 & 15.9 & Киргизтан & 3.8 & 3.2 & 2.6 \\
\hline Азербайджан & 18.0 & 20.4 & 12.4 & Казахстан & 4.6 & 3.7 & 2.3 \\
\hline Казахстан & 21.3 & 16.2 & 7.3 & Україна & 3.1 & 1.7 & 1.8 \\
\hline
\end{tabular}


ДОХОДИ ВІД РЕАЛІЗАЦІЇ ПОСЛУГ ШСД, У ФАКТИЧНИХ ЦІНАХ З ПДВ [12]

\begin{tabular}{|c|c|c|c|}
\hline & $\begin{array}{l}\text { I півріччя } \\
2017 \text { р., } \\
\text { млн грн }\end{array}$ & $\begin{array}{l}\text { I півріччя } \\
2018 \text { р., } \\
\text { млн грн }\end{array}$ & $\begin{array}{c}\text { Темпи росту / } \\
\text { падіння, \% }\end{array}$ \\
\hline \multicolumn{4}{|l|}{ f-ШСД, уього, у т.ч.: } \\
\hline абонентна плата за користування & 3486,8 & 4053,0 & 116,2 \\
\hline передача даних & 1629,2 & 1793,1 & 110,1 \\
\hline \multicolumn{4}{|l|}{ у т.ч.: } \\
\hline цифрові абонентські лінії & 1102,5 & 1145,7 & 103,9 \\
\hline волоконно-оптичні підключення & 1547,9 & 1897,0 & 122,6 \\
\hline локальні мережі & 384,4 & 156,1 & 40,6 \\
\hline модемні підключення до мереж кабельного телебачення & 312,3 & 392,1 & 125,6 \\
\hline m-ШСД, усього, з нього: & 1111,4 & 1268,7 & 114,2 \\
\hline мереж рухомого (мобільного) зв'язку & 1014,1 & 1157,8 & 114,2 \\
\hline фіксованих безпроводових каналів зв’язку & 96,4 & 109,8 & 113,9 \\
\hline супутникових каналів зв’язку & 0,9 & 1,1 & 115,7 \\
\hline
\end{tabular}

Цю проблему телекоми і регулюючі органи, уряди вирішують по-різному. Так, в розвинених країнах реалізують сценарій розширення ринку за рахунок розширення надання послуг за технологіями великих даних, штучного інтелекту, Інтернету речей, блокчейну. Країни, що розвиваються, здебільшого йдуть шляхом збільшення цін, податків (в Україні до тарифу на мобільний зв'язок входить збір у 7,5 \% до Пенсійного фонду, підсумкове податкове навантаження - 27,5\%). Крім того, значні капітальні витрати компаній на придбання ліцензій та рентну плату також закладаються в тарифи і покриваються за рахунок користувачів. Публікація даних в цьому розрізі, у том числі в регіональному розрізі, була 6 дуже корисною для потенційних інвесторів сектору.

Зведемо у таблицю дані щодо можливость часткової адаптації поточної офіційної статистики України до показників DESI (табл. 11). 3 неї випливає, що це неможливе за збереження наявних в Україні підходів.

Щодо показника $1 \mathrm{~b} 3$ Spectrum DESI (виконання необхідних заходів для використання необхідного РЧР для надання послуги т-ШСД), який з 2018 р. не розраховується в ЄС, оскільки його цілі досягнуті, для України моніторинг його аналога важливий. Більше того, його необхідно значно розширити, як для країни з перехідною економікою, де лише формуються інституційні засади ринкової економіки та суспільства та має місце значне технологічне відставання. В Україні треба створити аналог показника $1 \mathrm{~b} 3$ Spectrum для країн, що розвиваються, і включити до складу показників, що його формують,: 1) індикатори охоплення ШСД різних видів економічної діяльності (натепер діють виключнення), підприємств різного розміру, 2) ступінь конкурентності операторів і провайдерів (особливо зі значною ринковою часткою), 3) якості надання послуг, 4) фінансового стану підприємств, що надають послуги ШСД (прибутки, рентабельність, ARPU), 5) ступеня технологічного забезпечення експлуатації ШСД (за технологіями підключення і доступу, Інтернет- протоколів (IP), особливо щодо IPv6, що уможливлює NGA, тим більше, що вони Держстатом збираються [7], проте не публікуються, 5) регіональний аспект впровадження ШСД в важкодоступних регіонах (гірських), 6) механізми оплати (з предоплатою чи без), 7) соціальний аспект - загальний та регіональний стан підключення шкіл, закладів медицини, культури, регіональних органів влади, відділень поліції тощо до ШСД, 8) показники застосування принципу мережевої нейтральності (оператори електронних комунікацій не можуть обмежувати доступ кінцевих користувачів до законного змісту, веб-сайтів або платформ), 9) фактичний обсяг трафіку, який відбувся внаслідок ШСД, 10) розрахунок традиційного для $€ C$ показника $1 \mathrm{~b} 3$ Spectrum також $є$ актуальним для України, оскільки $є$ багато проблем з перерозподілом РЧР у зв'язку 
3 розгортанням в Україні 5G-зв'язку, оскільки потрібний для 5G діапазон РЧР (700-800МГц, 20 ГГц) вже використовується силовими відомствами і телевізійними мовниками [13].

Крім цього чи до аналога показника 1b3 Spectrum в частині інвестиційного забезпечення впровадження і розвитку ШСД і до нормативних показників для розробки Національного плану розвитку ШСД доцільні наступні, взяті за прикладом діючих Національних планів (стратегій) та регіональних програм, 3 зазначенням діапазону змін: 1) обсяг фінансової підтримки державою побудови роздрібної ШСД-мережі в регіонах з невдачами на ринку на побудову зв’ язку «останньої милі»; 2) обсяг державного заохочення переходу до IPv6 (Internet Protocol version 6) - нова версія Інтернет про- токолу (IP) для вирішення проблем попередньої версія (IPv4) за рахунок використання адрес довжини 128 біт замість 32 біт) у державному та приватному секторі; 3) частки аукціонної виручки від продажу РЧР, що надійшла на розбудову мереж NGA; 4) обсяг і частки співфінансування - державного, з боку місцевих бюджетів, бюджетів ОТГ, коштів донорів, приватного бізнесу на програми розвитку ШСД, 3 них ті, що мають сприяти росту інновацій та зайнятості особливо в сфері малого і середнього бізнесу, 5) розподіл коштів на програми розвитку ШСД за отримувачами (реципієнтами) - територіальними громадами, з них ОТГ, державними та приватними підприємства, 6) обсяг і частки інвестицій в рамках державноприватного партнерства.

Таблиия 11

\section{МОЖЛИВІСТЬ / НЕМОЖЛИВІСТЬ АДАПТАЦІЇ ОФІЦІЙНОЇ СТАТИСТИКИ УКРАЇНИ ДО ІНДИКАТОРІВ DЕSI}

\begin{tabular}{|c|c|c|c|}
\hline Підмасив & Індикатор DESI & $\begin{array}{c}\text { Можливість / неможливість адаптації / } \\
\text { офіційної статистики України до індикаторів DESI }\end{array}$ & Так / ні \\
\hline \multirow[b]{2}{*}{ 1a. f-ШСД } & $\begin{array}{l}\text { 1a1. Покриття } \\
\text { f- ШСД }\end{array}$ & $\begin{array}{l}\text { 1) використовується показник кількості абонентів f-ШСД, } \\
\text { що не тотожно до «домогосподарств». } \\
\text { 2) не подається охоплення за технологіям доступу }\end{array}$ & ні \\
\hline & $\begin{array}{l}\text { 1а2. Підписка } \\
\text { домогосподарств } \\
\text { на f-ШСД }\end{array}$ & $\begin{array}{l}\text { 1) використовується показник кількості абонентів f-ШСД, } \\
\text { що не тотожно до «домогосподарств». } \\
\text { 2) не подається охоплення за технологіям доступу, хоча або- } \\
\text { нентів f-ШСД можна вважати підписчиками } \\
\text { 3) Держстат не використовує поняття «підписка» }\end{array}$ & ні \\
\hline \multirow{3}{*}{ 1b. m-ШСД } & 1b1. покриття 4G & $\begin{array}{l}\text { подається окремими операторами, країнової офіційної } \\
\text { статистики не подається }\end{array}$ & ні \\
\hline & $\begin{array}{l}\text { 1b2. Підписка } \\
\text { на m-ШСД }\end{array}$ & $\begin{array}{l}\text { можна певною мірою вважати тотожним до показика } \\
\text { в Україні в разі тотожності понять «абонент» } \mathrm{i} \text { «підписчик». } \\
\text { Держстат таке поняття не використовує }\end{array}$ & частково \\
\hline & 1b3. Spectrum* & не розраховується в Україні & ні \\
\hline \multirow{2}{*}{$\begin{array}{l}\text { 1с. Швидкий } \\
\text { ШСД }\end{array}$} & $\begin{array}{l}\text { 1с1. Охоплення } \\
\text { швидким ШСД }\end{array}$ & $\begin{array}{l}\text { 1) використовується показник кількості абонентів ШСД, } \\
\text { що не тотожно до «домогосподарств», } \\
\text { 2) Держстат не подає статитстики ШПд в таких діапазонах } \\
\text { швидкості і за технологіями доступу }\end{array}$ & ні \\
\hline & $\begin{array}{l}\text { 1с2. Підписка } \\
\text { на швидкий } \\
\text { ШСД }\end{array}$ & $\begin{array}{l}\text { 1) використовується показник кількості абонентів ШСД, } \\
\text { що не тотожно до «домогосподарств», } \\
\text { 2) Держстат не подає статитстики ШПд в таких діапазонах } \\
\text { швидкості } \\
\text { 3) Держстат не використовує терміну «підписка» }\end{array}$ & ні \\
\hline \multirow{2}{*}{$\begin{array}{l}\text { 1d. Над- } \\
\text { швидкий } \\
\text { ШСД }\end{array}$} & $\begin{array}{l}\text { 1d1. Надшвидкий } \\
\text { ШІС, охоплення }\end{array}$ & \multirow{2}{*}{$\begin{array}{l}\text { 1) використовується показник кількості абонентів ШСД, } \\
\text { що не тотожно до «домогосподарств», } \\
\text { 2) Держстат не подає статитстики ШПд в таких діапазонах } \\
\text { швидкості і за технологіями доступу } \\
\text { 3) Держстат не використовує терміну «підписка» }\end{array}$} & ні \\
\hline & $\begin{array}{l}\text { 1d2. Надшвидкий } \\
\text { ШСД, підписка }\end{array}$ & & ні \\
\hline $\begin{array}{l}\text { 1е. Індекс цін } \\
\text { ШСД }\end{array}$ & $\begin{array}{l}\text { 1е1. Індекс цін } \\
\text { ШСД }\end{array}$ & $\begin{array}{l}\text { подається окремими операторами, країнової офіційної стати- } \\
\text { стики не подається, подібну інформацію публікує MCE, про- } \\
\text { те набори кошиків послуг не співпадають з DESI }\end{array}$ & ні \\
\hline
\end{tabular}

* Примітка. Не розраховується з 2018 р. через досягнення проголошених цілей. 
Слід зазначити, що статистичне табло DESI $€$ динамічним, воно відображає нові тенденції сфери. Так, в рішеннях Еврокомісії зазначається про задоволення майбутніх потреб в ШСД, які мають знайти своє відображення в DESI. Зокрема, Єврокомісія пропонує, щоб до 2025 р. всі школи, транспортні вузли та основні постачальники державних послуг, підприємства з інтенсивним цифровими правами мали доступ до інтернет-з'єднанням зі швидкістю завантаження / вивантаження даних 1 Гбіт/с. Крім того, всі європейські домогосподарства, сільські або міські, повинні мати доступ до мереж, що пропонують швидкість завантаження вище 100 Мбіт/с, яку можна підвищити до 1 Гбіт/с, а у всіх міських районах, а також на великих автомобільних і залізних дорогах має функціонувати безперебійній $\mathrm{m}-Ш С Д$ 5G, починаючи 3 повноцінного комерційного обслуговування принаймні в одному великому місті в кожній країні-члені ЕС уже до 2020 р. [14].

\section{ВИСНОВКИ ТА ПЕРСПЕКТИВИ \\ ПОДАЛЬШИХ ДОСЛІДЖЕНЬ}

Офіційна статистика в Україні має перейти на стандарти обліку DESI в частині ШСД, в тому числі з впровадженням його методологічних підходів щодо діапазонів швидкостей, технологій надання послуг ШСД, об'єктів надання послуг, способів укладання між підписчиками i надавачами. Для адаптації в Україні Індексу цін ШСД DESI має бути сформований аналогічний DESI базовий кошик послуг ШСД і їх ціни.

Для України дуже важливий моніторинг аналога показника DESI $1 \mathrm{~b} 3$ - індексу Spectrum. Проте його необхідно значно розширити, як для країни з перехідною економікою, де лише формуються основні інституційні засади економіки та суспільства і має місце значне технологічне відставання. До показників, що його формують, слід включити індикатори охоплення ШСД сфер економіки, конкурентності ринкового середовища, якості, технологічні, фінансові, інвестиційні показники, аспект регіональний та інституційний (фінансова підтримка держави, ШСД в е-урядуванні, доходи держави від продажу РЧР, співфінансування 3 різних джерел, державно-приватне партнерство). Доцільні для наслідування й підходи інших міжнародних організацій в цій сфері. Всі ці заходи треба здійснити найближчим часом для подальшого моніторингу ситуації.

\section{СПИСОК ВИКОРИСТАНИХ ДЖЕРЕЛ}

1. Про схвалення Концепції розвитку цифрової економіки та суспільства України на 2018-2020 pp. Розпорядження Кабінету Міністрів України від 17.01.2018 p. № 67-p. URL: https://www.kmu.gov.ua/ ua/npas/pro-shvalenny

2 Digital Economy and Society Index. European Commission. 2018. URL: https://ec.europa.eu/digitalsingle-market/en/desi (дата звернення: 1.12.2018)

3. Statistical reports Measuring the Information Society Report Volume 1. ITU Publications. 2018. URL: https://www.itu.int/en/ITU- D/Statistics/Documents/.../misr2018/MISR-2018-Vol-1-E.pdf (дата звернення: 21.02.2019)

4 The State of Broadband: Broadband catalyzing sustainable development September 2018. UN Broadband Commission for Digital Development/. URL:https://www.itu.int/dms_pub/itu-s/opb/pol/SPOL-BROADBAND.19-2018-PDF-E.pdf (дата звернення: 19.05.2019)

5. Зелена книга "Регулювання ринку фіксованого широкосмугового доступу до мережі інтернет" Офіс ефективного регулювання. 2 червня 2017 p. URL:https://regulation.gov.ua/book/27-zelenakniga-reguluvanna-rinku-fiksovanogo-sirokosmugovogo-dostupu-do-merezi-internet (дата звернення 15.05.2019)

6. Стан і розвиток зв’язку. Держстат України. Київ. 2019. URL: http://www.ukrstat.gov.ua/ (дата звернення: 30.12.2018)

7. Альбом форм державних статистичних спостережень. Держстат України. Київ. 2019. URL: http:// www.ukrstat.gov.ua/ (дата звернення: 30.12.2018)

8. Витрати і ресурси домогосподарств України (за даними вибіркового обстеження умов життя домогосподарств) за 9 місяціві 2018 р. (статистичний бюлетень). Доходи та умови життя. Держстат України. Київ. 2019. URL: http://www.ukrstat.gov.ua/operativ/operativ2007/gdvdg_rik/dvdg_u/str_ vut2010_u.htm (дата звернення: 9.01.2019)

9. Клочкова Е.Н. Инструментарий оценки развития информационного общества в условиях глобализации. Методические подходы и причины дифференциации. 2017, Проспект. Москва (дата звернення: 18.05.2019)

10. Measuring the Information Society Report 2017. ITU. URL https://www.itu.int/en/ITU-D/Statistics/Pages/ publications/mis2017.aspx (дата звернення: 19.05.2019) 
11. «Київстар» вклав у зв'язок четвертого покоління 7 млрд грн у 2018 p. URL: https://mind.ua/ news/20194903-kiyivstar-vklav-u-zvyazok-chetvertogo-pokolinnya-7-mlrd- grn-u-2018-roci (дата звернення: 19.05.2019)

12 Галузь зв'язку: цифри та факти. HKP3I. URL:https://nkrzi.gov.ua/index.php?r=site/ index\&pg=150\&language $=$ uk (дата звернення 9.01.2019)

13. Запуск 5G-связи в Украине возможен уже с 2020 года - глава регулятора. URL: https:/gordonua.com/ news/science/zapusk-5g-svyazi-v-ukraine-vozmozhen-uzhe-s- 2020-goda-glava-regulyatora-967583.html (дата звернення: 22.05.2019)

14. Connectivity for a European Gigabit Society. European Commission. URL:https://ec.europa.eu/digitalsingle-market/en/policies/improving-connectivity-and- access (дата звернення: 22.05.2019)

\author{
Дульская Ирина Васильевна \\ Государственное учреждение «Институт экономики и прогнозирования» НАН Украины, \\ Киев, Украина \\ ORCID 0000-0002-2657-8375 \\ e-mail:i_dulska@i.ua
}

\title{
ПРОБЛЕМЫ АДАПТАЦИИ СТАТИСТИКИ ШИРОКОПОЛОСНОГО ДОСТУПА К СЕТИ ИНТЕРНЕТ В УКРАИНЕ К МЕЖДУНАРОДНЫМ ИНДИКАТОРАМ
}

Аннотация. В статье исследуются методологические проблемы адаптации статистики широкополосного доступа в Интернет (ШПД) Украины к международным индикаторам сферы - европейского цифрового табло и индекса DESI в части ШПД, индикаторов других международных организаций в этой сфере.

Установлено, что из-за невыполнения правительственных решений по определению индексов, индикаторов и методики оценки цифрового развития Украины в соответствии с международными практиками, официальная статистика продолжает использовать показатели, которые не позволяют в полной мере осуществлять международные сравнения, разрабатывать стратегические документы относительно перспектив развития ШПД в стране. Не гармонизированы с европейскими подходами анализ диапазонов скоростей ШПД. Это не позволяет оценивать степень проникновения передовых технологий (обычный, быстрый, сверхбыстрый ШПД). Данные по покрытию 3-4G технологиями связи фрагментарны. Отличаются терминологические подходы к определению технологий подключения и передачи данных, объектов оказания услуг (в ЕС им является домохозяйство, в Украине - абонент), способа установления договорных отношений по предоставлению услуг ШПД (контракт с идентификацией подписчика или анонимная подписка). В Украине в значительной мере официально не публикуется статистика, которая требуется от субъектов хозяйствования согласно форм государственных статистических наблюдений. В тоже время Международный Союз Электросвязи публикует значительный диапазон статистических данных, которые не обнародует офичиальная статистика в Украине - финансовые показатели, объем инвестиций, чен (не совпадают с европейскими подходами к формированию услуг корзине ШПД), налоговая нагрузка на потребителей услуг ШПД.

Предложена структура формирования в Украине аналога показателя DESI 1 b3 Spectrum, который в ЕС не рассчитывается с 2018 г., поскольку его чели достигнуты. Для страны с переходной экономикой, где только формируются институциональные основы рыночной экономики, общества и есть значительное технологическое отставание, он является целесообразным. $B \mathrm{cma-}$ тистическую базу следует своевременно вносить показатели, которые отражают новые явления в сфере, например, степень развития $5 \mathrm{G}$.

Ключевые слова: широкополосный доступ к Интернет (ШПД); фиксированный и мобильный ШПД; европейское цифровое табло DESI в части ШПД; статистика ШПД в Украине; совместимость показателей; скорость ШПД; абонент ШПД; подписка на ШПД; цены корзины услуг ШПД. 


\section{Iryna V. Dulska}

Ph.D. in Economics, Senior Researcher

State institution "Institute of Economics and Forecasting"

of the National Academy of Sciences of Ukraine,

Kyiv, Ukraine

ORCID 0000-0002-2657-8375

e-mail: i_dulska@i.ua

\section{BROADCAST INTERNET ACCESS STATISTICS ADAPTATION PROBLEMS IN UKRAINE TO INTERNATIONAL INDICATORS}

Abstract. The article deals with the methodological problems of the adaptation of the statistics of broadband access to the Internet (BB) in Ukraine to the international indicators of the sphere - the European digital scoreboard and the DESI index in the part of the BB, indicators of other international organizations in this area.

It is established that due to non-fulfillment of government decisions on the determination of indices, indicators and methods of evaluating the digital development of Ukraine in accordance with international practices, official statistics continue to use indicators that do not allow to fully implement international comparisons, to develop strategic documents on the prospects of development of BB in the country. The analysis of the broadband speeds range is not harmonized with the European approaches. This does not allow to assess the degree of penetration of advanced technologies (ordinary, fast, ultrafast BB). Data on the coverage of 3-4G communication technologies are fragmentary. Different terminological approaches to the definition of the technologies of connection and data transmission, objects of service provision (in the EU it is a household, in Ukraine is a subscriber), a way of establishing contractual relations for the provision of services to the BB (contract with subscriber identification or anonymous subscription). In Ukraine, the statistics required by business entities in accordance with the forms of state statistical surveys are largely not officially published in Ukraine. At the same time, the International Telecommunication Union publishes a significant range of statistics that are not published by official statistics in Ukraine - financial indicators, amount of investments, prices (do not coincide with the European approaches to the formation of services of the basket of $B B)$, tax burden on consumers of services of the $B B$.

Article proposes the structure of the formation in Ukraine analogue of the indicator of DESI 1 b3 Spectrum, which in the EU is not calculated from 2018, because the goals have been achieved. For a country with a transition economy, where only the institutional foundations of a market economy, society are formed and there is a significant technological lag, it is expedient. The statistical base should be timely introduced indicators that reflect new phenomena in the field, for example, the degree of development of $5 \mathrm{G}$.

Keywords: broadband access to the Internet (BB); fixed and mobile BB; European Digital Display DESI of BB; $B B$ statistics in Ukraine; compatibility; speed of $B B ; B B$ subscriber; prices of the basket of services of the $B B$

\section{REFERENCES (TRANSLATED AND TRANSLITERATED)}

1. About the conceptualization of the development of the digital economy for Ukraine and Ukraine for 20182020 p. The order cabinet of Ministers of Ukraine, Jan. 17, 2018. No. 67-p. URL: https://www.kmu.gov.ua/ ua/npas/pro-shvalenny (last access: 15.05.2019) (in Ukrainian)

2. Digital Economy and Society Index. European Commission. 2018. URL: https://ec.europa.eu/digital-single-market/en/desi (last access: 1.12.2018) (in English)

3. Statistical reports Measuring the Information Society Report Volume 1. ITU Publications. 2018. URL: https://www.itu.int/en/ITU-D/Statistics/Documents/.../misr2018/MISR-2018-Vol-1-E.pdf (last access: Feb. 21, 2019) (in English)

4. The State of Broadband: Broadband September 2014. UN Broadband Commission for Digital Development. URL: https: //www.itu.int/dms_pub/itu-s/opb/pol/S-POL-BROADBAND. 19-2018-PDF-E.pdf (last access: May 19, 2019) (in English)

5. Green book "Regulatory market of wide wide-access access to the Internet" Office of effective regulation. 2017. URL: https: //regulation.gov.ua/book/27-zelena-kniga-reguluvanna-rinku-fiksovanogo-sirokosmugovogo-dostupu-do-merezi-internet (last access: May 15, 2019) (in Ukrainian) 
6. Status and development of communication. Derzhstat Ukrayiny’. Ky'yiv. 2019. URL: http://www.ukrstat. gov.ua/ (last access: Dec. 30, 2018) (in Ukrainian)

7. Album of the forms of state statistics. Derzhstat Ukrayiny'. Ky'yiv 2019. URL: http://www.ukrstat.gov.ua/ (last access: Dec. 30, 2018) (in Ukrainian)

8. Costs and resources of households in Ukraine (according to the sample survey of living conditions of households) for 9 months of 2018 (statistical bulletin). Income and living conditions. Derzhstat Ukrayiny'. Ky'yiv. URL: http://www.ukrstat.gov.ua/operativ/operativ2007/gdvdg_rik/dvdg_u/str_vut2010_u.htm (last access: Jan. 9, 2019) (in Ukrainian)

9. Klochkova E.N. A toolkit for assessing the development of the information society in the context of globalization. Methodical approaches and reasons for differentiation. 2017. Prospect. Moscow (last access: May 18, 2019) (in Russian)

10. Measuring the Information Society Report 2017. ITU. URL https:/www.itu.int/en/ITU-D/Statistics/Pages/ publications/mis2017.aspx (last access: May 19, 2019) (in English)

11. "Kyivstar" in the clumps of the fourth generation linking 7 billion UAH from 2018 p. URL: https://mind. ua/news/20194903-kiyivstar-vklav-u-zvyazok-chetvertogo-pokolinnya-7-mlrd-grn-u-2018-roci (last access: May 19, 2019) (in Ukrainian)

12. Branch of communication: figures and facts. NKRZI. URL: https: //nkrzi.gov.ua/index.php? R = site / index $\& p g=150$ \& language $=u k$ (last access: Jan. 9, 2019) (in Ukrainian)

13. The launch of $5 \mathrm{G}$-communications in Ukraine has been possible since 2020 - the head of the regulator. URL: https://gordonua.com/news/science/zapusk-5g-svyazi-v-ukraine-vozmozhen-uzhe-s-2020-godaglava-regulyatora-967583.html (last access: May 22, 2019) (in Russian)

14. Connectivity for a European Gigabit Society. European Commission. URL: https: //ec.europa.eu/digital-single-market/en/policies/improving-connectivity-and-access (last access: May 22, 2019) (in English) 